\title{
Modelling of foundation response to scour and scour protection for offshore wind turbine structures
}

\author{
R.O. Mayall, B.W. Byrne, H.J. Burd \& R.A. McAdam \\ Department of Engineering Science, University of Oxford, Oxford, United Kingdom \\ P. Cassie \\ E.ON Climate \& Renewables, Coventry, United Kingdom
}

R.J.S. Whitehouse

HR Wallingford, Wallingford, United Kingdom

\begin{abstract}
Local and global scour around offshore monopile wind turbine structures can cause a reduction in foundation strength and stiffness, and a consequential reduction in the structure's natural frequency. To devise optimal scour remediation schemes, it is necessary to develop an understanding of the interactions between scour development, soil-foundation stiffness, and the dynamic response of the structure. This paper describes a research project that develops a framework to assess the influence of scour and scour remediation systems on the dynamic characteristics of offshore wind turbine structures. The research project includes one-dimensional (1D) finite element modelling, calibrated using three-dimensional (3D) finite element analysis, experimental measurements, and monitored field data. The paper outlines the development of the 1D and 3D finite element models, as well as a novel experimental programme carried out on a 1:20 scale offshore wind structure in the Fast Flow Facility at HR Wallingford, UK.
\end{abstract}

\section{INTRODUCTION}

Loss of soil support around offshore wind turbine monopile structures, due to scour, can cause a drop in the structure's natural frequency due to the loss of foundation stiffness. Local scour around piles, and the effect of moving bed-forms such as sand waves, can be onerous at sites with high currents (e.g. Høgedal \& Hald, 2005; Larsen et al., 2016; Tseng et al., 2017). At such sites it is important to incorporate scour processes and/or scour protection into the wind farm design.

E.ON Climate \& Renewables and HR Wallingford are jointly funding an ongoing research project at the University of Oxford that investigates the effect of scour and scour protection on wind turbine structures. The focus of the research is on assessing the influence of scour and scour remediation systems on the dynamic characteristics (frequencies and mode shapes) of monopilesupported offshore wind turbine structures. Fig. 1 presents the framework of the research project, which includes one-dimensional (1D) and three-dimensional (3D) finite element analysis (FEA) validated using experimental work, supported by field data. It is anticipated that this framework can be applied to the design of future offshore wind farms, the selection of scour protection systems for future or operating wind farms, and for the lifetime assessment of existing scour-affected assets.

\section{BACKGROUND}

\subsection{Scour at Offshore Foundations}

Scour around offshore foundations can take the form of global seabed scour or local scour, and both types of scour can be present. Table 1 and Fig. 2 present a summary of the adopted definitions of global and local scour. The development of scour is influenced by the site wave and current environment, the character of the seabed sediments, the local geology, and the properties of the structures and infrastructure placed on the seabed.

\subsection{Natural Frequency of Wind Turbine Structures}

Monopile wind turbines are typically designed for the resonant frequency (first natural frequency) to be above the rotor frequency band (1P) and below the

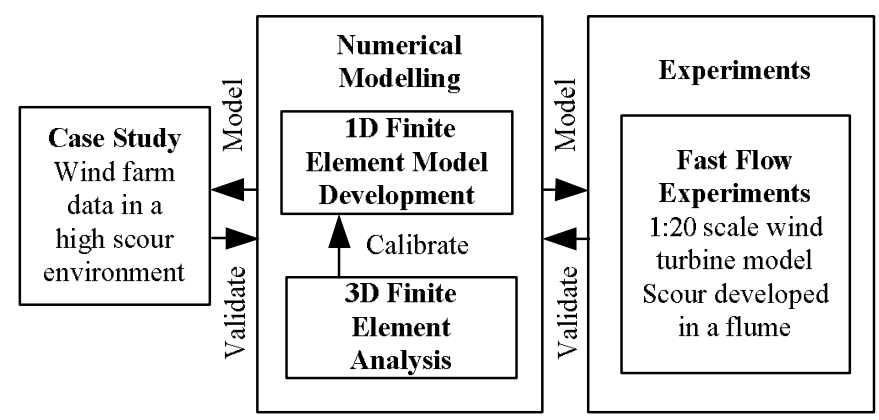

Figure 1. Research project framework. 
blade passing frequency band (3P) (Kallehave et al., 2015).

Removal of soil by scour causes a loss of foundation stiffness, so that the natural frequency moves closer to $1 \mathrm{P}$. This leads to increased dynamic amplification of the rotor frequency loads and consequently increased fatigue damage within the structure. For accurate predictions of natural frequencies it is important to suitably model the stiffness of the foundation itself, including the effect that any scour and scour protection has on the foundation response.

\subsection{Pile Foundation Analysis}

Design standards for offshore structures (e.g.

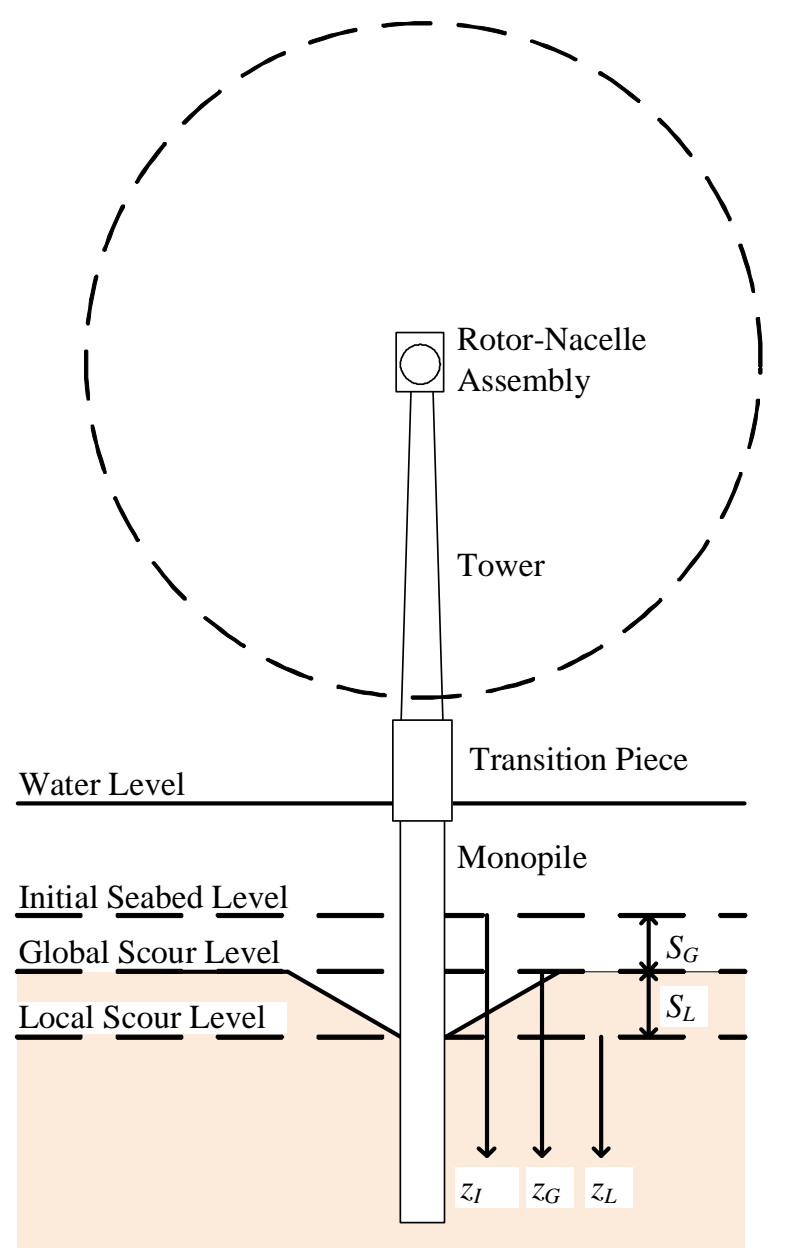

Figure 2. Scour around a monopile offshore wind turbine (adapted from Mayall et al., 2018).
DNVGL, 2016; API, 2011; ISO, 2007) recommend that the lateral load-displacement behaviour of piles should be predicted using a nonlinear Winkler spring method within a 1D model, with the soil represented by discrete $p-y$ curves. The PISA project (Byrne et al., 2015; Zdravković et al., 2015) proposes a more comprehensive model of the soil resistance for monopile design incorporating the distributed lateral reaction, distributed moment due to the rotation of the pile cross-section, plus moment and shear reaction at the base of the pile. The PISA approach recommends calibrating the soil resistance curves using 3D FEA of the load-displacement behaviour, where the initial pile response is defined as a function of small strain shear stiffness $\left(G_{0}\right)$ of the soil.

\subsection{Effects of Scour on Monopile Behaviour}

\subsubsection{Global Scour}

For global scour it is generally accepted that soil stresses can be calculated assuming that the removed layers have no residual effects on the stresses (e.g. DNVGL, 2016; Qi et al., 2016). Vertical effective stresses under global scour $\left(\sigma_{V G}^{\prime}\right)$ can be calculated using the depth below the lowered seabed level $\left(z_{G}\right)$.

\subsubsection{Local Scour}

Under local scour, the design standards (e.g. API, 2011) recommend using reduced effective stresses, which return linearly to the globally-scoured background condition over a defined overburden reduction depth. An alternative hyperbolic return is proposed by Qi et al. (2016). Note that both methods are intended for capacity predictions, rather than for small displacement problems.

The calculation of vertical effective stress adjacent to the pile for local scour conditions $\left(\sigma_{V L}^{\prime}\right)$ can be expressed using an effective soil depth $\left(z_{e}\right)$ :

$\sigma_{V L}^{\prime}=z_{e} \gamma_{a v}^{\prime}$

The effective soil depth can be calculated using a local scour influence factor $\left(\alpha_{L}\right)$ between 0 and 1 ; as presented in Fig. 3 for the API (2011) and Qi et al. (2016) methods.

Table 1. Summary of Scour Definitions Adopted in this Research for Offshore Foundations.

\begin{tabular}{|c|c|c|}
\hline Scour Type & Description & Remarks \\
\hline Global Scour & $\begin{array}{l}\text { Overall seabed movement, for example: } \\
\text { - Migrating sandwaves and sandbanks } \\
\text { - Migrating channel features }\end{array}$ & $\begin{array}{l}\text { Some references use the terminology general scour } \\
\text { (e.g. API, 2011; DNVGL, 2016), rather than global } \\
\text { scour (e.g. ISO, 2007). An alternative definition of global } \\
\text { scour is dishpan scour around jacket structures. }\end{array}$ \\
\hline Local Scour & $\begin{array}{l}\text { A scour pit around a foundation caused by } \\
\text { the formation of horseshoe vortices around } \\
\text { the pile in a flow. Local scour pits may be } \\
\text { asymmetric, with deposition downstream. }\end{array}$ & $\begin{array}{l}\text { Recommended design local scour depths are based on } \\
\text { empirical data (e.g. Breusers et al., 1977). Some design } \\
\text { standards (API, 2011; ISO, 2007) recommend a design } \\
\text { local scour depth of } 1.5 \text { D; DNVGL (2016) recommends } \\
\text { a design local scour depth of } 1.3 \text { D. More recent emprical } \\
\text { methods are available (e.g. Tavouktsoglou et al., 2017). }\end{array}$ \\
\hline
\end{tabular}




\subsubsection{Effect of Scour on Structural Dynamics}

There are a number of influences of scour on the foundation behaviour. Firstly, the stiffness of the soil response may reduce, secondly as there is less embedment the combined response is more flexible, and thirdly a larger free length of tower is more flexible. Several numerical studies in the literature make use of 1D models to predict the effect of scour on the natural frequency of monopile wind turbines; a selection are collated in Table 2. The predicted sensitivity of natural frequency to scour varies significantly between these studies; it is unclear if this is due to differences in the modelling approaches or simply due to the differences in the modelled structures and foundations.

Previous experimental tests (Prendergast et al., 2015) provide data on the change in natural frequency with scour for a uniform pile in dry conditions. The current research project includes models of a wind turbine tower and rotor-nacelle assembly (Mayall et al., 2018), which are felt influential on the overall dynamic behaviour of the structure.

\subsection{Scour Protection}

Scour protection can be installed before or after the foundation installation, and can be applied as a remedial measure where necessary. The primary function of scour protection is to prevent the development of scour at a foundation, but the presence of the placed material may also affect the overall foundation response.

Scour protection can take the form of rock fill, filled bags or nets, or mattresses. Rock armour or fill (also termed riprap) is the most common solution and usually consists of a rock or gravel fill. Scour protection bag and net solutions include filter units (rock-filled nets), grout bags, geobags (sand-filled bags), and tyre-filled nets. Mattress solutions include mudmats or collars, hinged plates, composite rubber mats, grout-filled mattresses, articulating concrete block systems, and fronded mats.

Other mitigation strategies include monitoring, structural modifications, and ground improvement. Each mitigation strategy has differing cost and risk implications, which can be significant when applied across an entire wind farm site.

\section{NUMERICAL MODELLING}

\subsection{One-Dimensional Finite Element Analysis}

A 1D FEA model has been developed to provide a method of predicting changes to the dynamic response of a monopile structure for varying scour and scour protection conditions. Fig. 4 presents the model configuration, which uses Euler-Bernoulli beam elements. Natural frequencies and mode

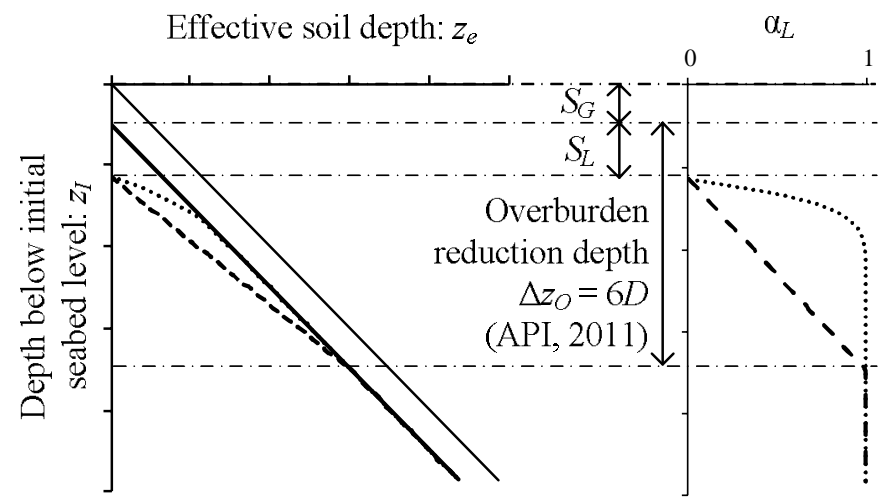

Global depth: $z_{G}=z_{I}-S_{G}$

Local depth: $z_{L}=z_{G}-S_{L}$

Effective soil depth: $z_{e}=z_{G}-S_{L}\left(1-\alpha_{L}\right)$

Unscoured profile

Globally Scoured Profile

--- Locally Scoured (API, 2011) $\left[\alpha_{L}=z_{L} /\left(\Delta z_{O}-S_{L}\right)\right]$

….... Locally Scoured (Qi et al., 2016) $\left[\alpha_{L}=\tanh \left(f\left(z_{L} / D\right)\right) ; f=1.5\right]$

Figure 3. Effective soil depth for calculation of stresses beneath local scour (after API, 2011 and Qi et al., 2016).

Table 2. Selected Numerical Studies on the Effects of Scour on Monopile Offshore Wind Turbine Natural Frequency.

\begin{tabular}{|c|c|c|c|c|}
\hline Reference & Description & Soil Description & Pile Model & Scour Model \\
\hline Tempel et al. (2004) & $\begin{array}{l}\text { Preliminary design at a test site, } \\
\text { analysis methods not stated }\end{array}$ & Not stated & $D=4.7 \mathrm{~m}$ & $\begin{array}{l}\text { Local scour, analysis methods } \\
\text { not stated }\end{array}$ \\
\hline $\begin{array}{l}\text { Damgaard et al. } \\
(2013)\end{array}$ & $\begin{array}{l}\text { First eigenfrequency calculated } \\
\text { using } p-y \text { initial stiffness; also } \\
\text { includes analysis of backfill }\end{array}$ & $\begin{array}{l}\text { Dense sand over } \\
\text { firm clay }\end{array}$ & $\begin{array}{l}D=4.3 \mathrm{~m} \\
\text { Embedment }=29.5 \mathrm{~m}\end{array}$ & $\begin{array}{l}\text { Local scour, vertical effective } \\
\text { stresses reduce linearly to } 3 D \\
\text { below the scour hole base }\end{array}$ \\
\hline $\begin{array}{l}\text { Sørensen and Ibsen } \\
\text { (2013) }\end{array}$ & $\begin{array}{l}\text { Eigenfrequency mode } 1 \text { and } \\
2 \text { calculated using } p-y \text { initial } \\
\text { stiffness; also includes analysis } \\
\text { of backfill (varying fill density) }\end{array}$ & Sand & $\begin{array}{l}D=4.0 \mathrm{~m} \\
\text { Embedment }=21.9 \mathrm{~m}\end{array}$ & $\begin{array}{l}\text { For local scour, only the } \\
\text { ultimate resistance of } p-y \\
\text { curves is modified and not } \\
\text { the initial slope }\end{array}$ \\
\hline $\begin{array}{l}\text { Prendergast et al. } \\
\text { (2018) }\end{array}$ & $\begin{array}{l}\text { Stochastic analysis, soil stiffness } \\
\text { from modulus of subgrade } \\
\text { reaction, model includes added } \\
\text { mass of external water }\end{array}$ & $\begin{array}{l}\text { Predominantly } \\
\text { medium dense } \\
\text { sand }\end{array}$ & $\begin{array}{l}D=6.0 \mathrm{~m} \\
\text { Embedment }=30 \mathrm{~m}\end{array}$ & $\begin{array}{l}\text { Sequential removal of soil } \\
\text { springs }\end{array}$ \\
\hline
\end{tabular}


shapes of the structure are calculated by performing an eigenvalue analysis, using the model's stiffness and mass matrices. The eigenvalue analysis outputs the same number of vibration modes as degrees of freedom in the system. These can be sorted in order of increasing frequency to identify the first few modes of vibration, as these are of interest.

The stiffness matrix includes contributions from beam elements to model the structure itself, and the initial stiffness of the pile-soil reaction curves from a PISA-type approach. The shear modulus of the soil at small displacements $\left(G_{0}\right)$ is used to define the initial pile-soil stiffness, where $G_{0}$ can be defined as a function of vertical effective stress (Clayton, 2011). To account for scour, $\sigma_{V L}^{\prime}$ can be calculated along the pile length and input to the $G_{0}$ calculation.

The mass matrix includes contributions from the pile-tower structure, rotor-nacelle assembly, soil plug, and internal and external water.

\subsection{Three-Dimensional Finite Element Analysis}

A 3D FEA model was developed using a configuration based on field-scale offshore wind turbines. Fig. 5 presents the model configuration, which includes a conical region to allow formation of a scour pit; the elements can be deactivated to simulate local scour. Alternatively the material properties of the cone can be varied to simulate scour protection. Global scour can be simulated by reducing the embedded pile length in the model. The mass and inertia of the rotor-nacelle assembly is modelled as a high stiffness disc.

A linear perturbation frequency analysis can be performed, which requires linear elastic assumptions and outputs vibration frequencies and mode shapes for the model from an eigenvalue analysis. The output includes the results for vibration modes that are not necessarily of interest, such as standing waves in the soil body or ovalising of the structure. The number of these modes increases with the number of degrees of freedom in the system.

In a preliminary model, the soil was modelled with a uniform stiffness, and the results were compared with the 1D model for the same structure and soil at field scale. For the unscoured case, the frequency predictions of the first three modes were within $1 \%$. For the scoured case, the frequency predictions of the first two modes were within $1 \%$ of each other, with a more significant $(5 \%)$ difference for the third mode of vibration.

\section{EXPERIMENTAL MODELLING}

\subsection{Scope of Experiments}

An experimental programme was carried out in the Fast Flow Facility at HR Wallingford, UK. This

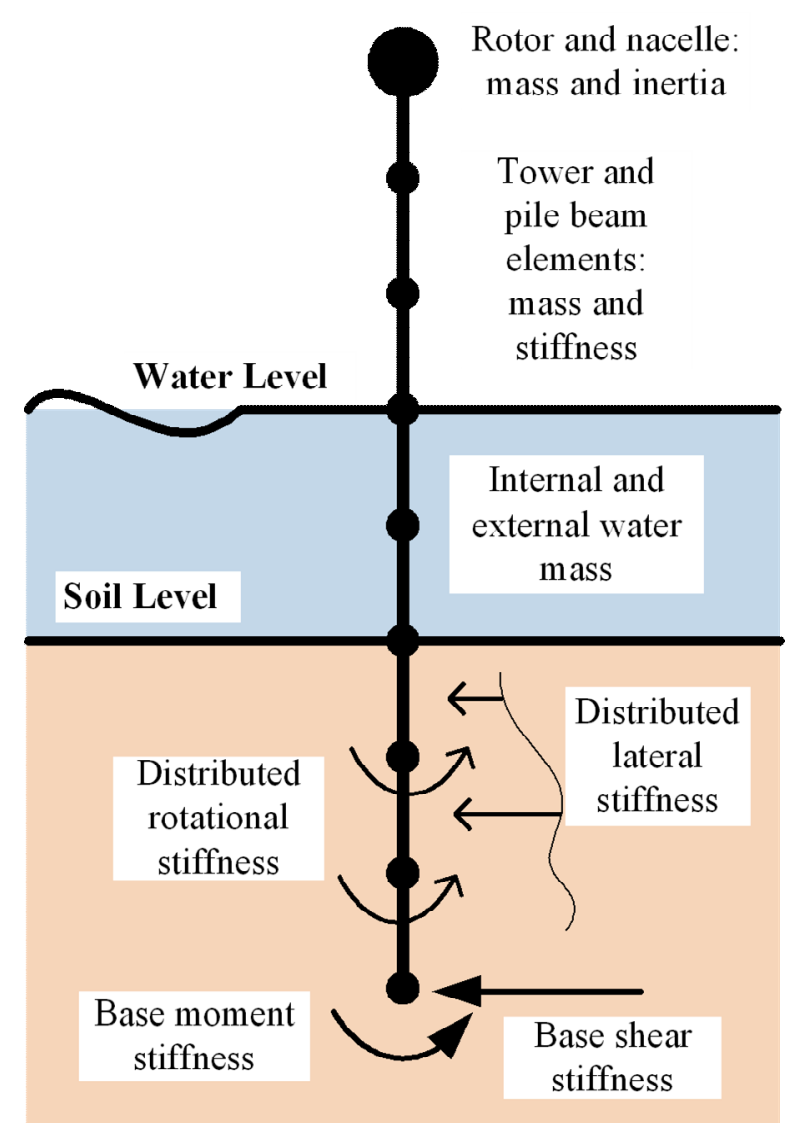

Figure 4. 1D Finite Element Model Configuration (number and length of elements not to scale).

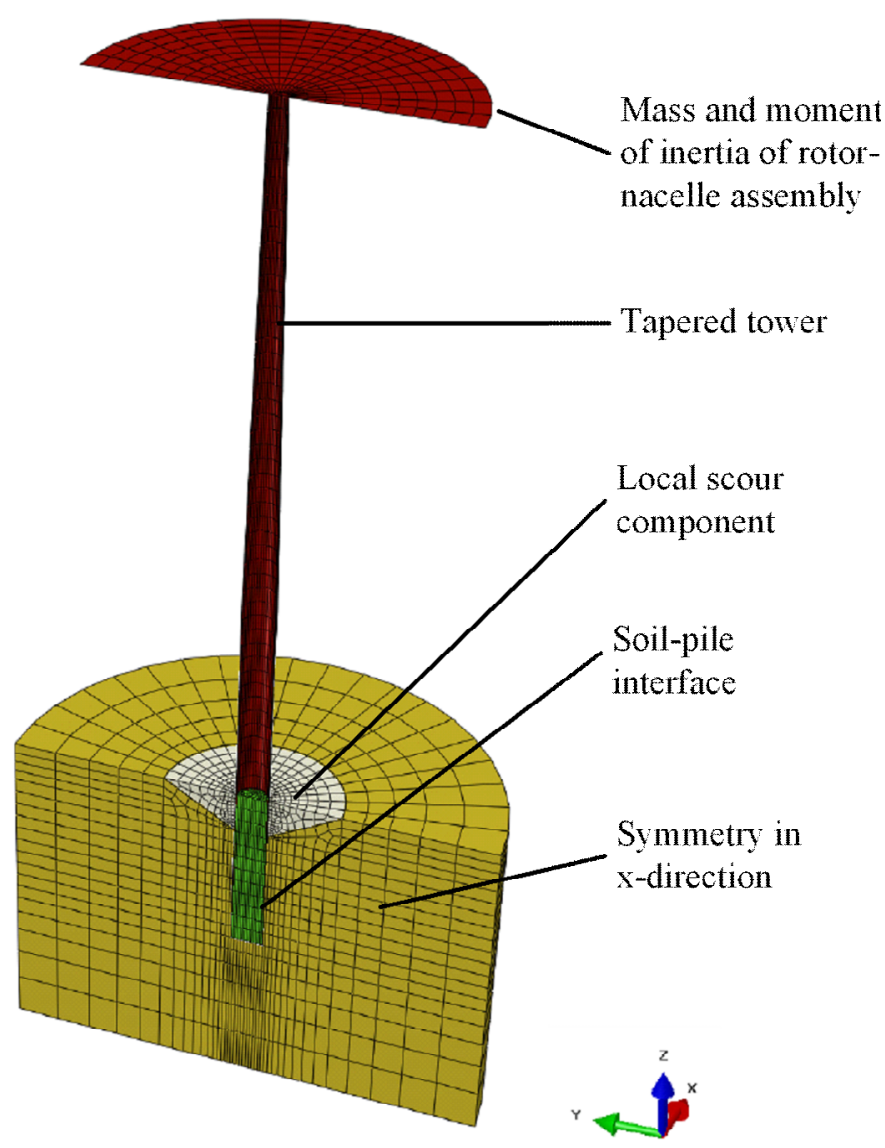

Figure 5. 3D Finite Element Model Configuration. 
experimental programme explored measurement of the dynamic and static response of a 1:20 scale offshore wind structure with flow-developed scour. Mayall et al. (2018) provide a detailed description of the experimental setup and procedures.

The model structure comprised a monopile-tower structure (Fig. 6) with a top mass to mimic the rotornacelle assembly. The structure was instrumented with accelerometers, force sensors, strain gauges and displacement sensors.

Six tests were performed in the Fast Flow Facility, incorporating variations in scour protection (Table 3). For each test, after flooding the flume to the required water depth, the pile was installed into a prepared sand bed. Reversing (tidal) flow was applied to produce local scour around the pile in live-bed conditions. Once the target local scour was achieved the scour protection (if any) was installed. Global scour was simulated by removal of temporary retaining bars upstream and downstream of the main test section and continued tidal flow.

Additional elements of the testing programme not described in this paper included cone penetration testing of the sand bed and monotonic lateral loading of the pile at the end of each test.

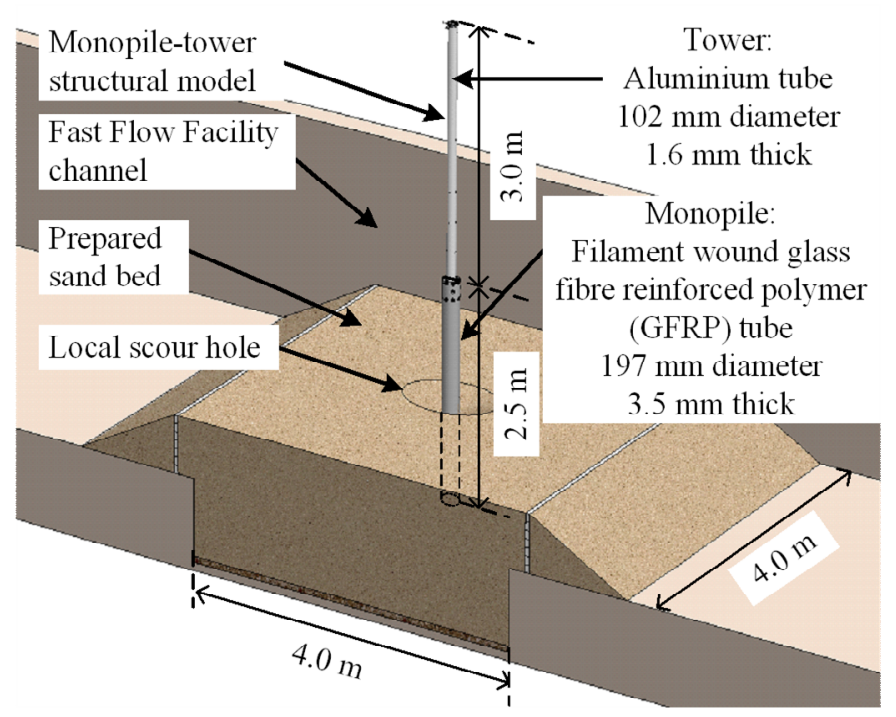

Figure 6. Fast Flow Facility experiment layout (from Mayall et al., 2018).

Table 3. Summary of Fast Flow Facility experiments.

\begin{tabular}{llll}
\hline $\begin{array}{l}\text { Test } \\
\text { Number }\end{array}$ & $\begin{array}{l}\text { Initial Global } \\
\text { Bed Level } \\
\text { Above Pile Tip }\end{array}$ & $\begin{array}{l}\text { Scour Depth } \\
\text { Prior to } \\
\text { Remediation }\end{array}$ & $\begin{array}{l}\text { Scour } \\
\text { Protection } \\
\text { Model }\end{array}$ \\
\hline 1 & $4.56 D$ & $1.58 D$ & None \\
2 & $4.61 D$ & $1.58 D$ & $\begin{array}{l}\text { Tyre-filled nets } \\
\text { Rock armour } \\
\text { remediation }(76 \mathrm{~kg}) \\
3\end{array}$ \\
$4.57 D$ & $1.49 D$ & $\begin{array}{l}\text { Rock armour } \\
\text { remediation }(22 \mathrm{~kg})\end{array}$ \\
4 & $4.55 D$ & $0.66 D$ & $\begin{array}{l}\text { Pre-installed rock } \\
\text { armour }(145 \mathrm{~kg})\end{array}$ \\
5 & $4.57 D$ & None & $\begin{array}{l}\text { Rock armour } \\
\text { remediation }(76 \mathrm{~kg})\end{array}$ \\
6 & $5.61 D$ & $1.51 D$ &
\end{tabular}

\subsection{Scour Protection Models}

\subsubsection{Rock Armour}

Rock armour scour remediation was installed in three tests; in each case the rock armour was placed to fill approximately $2 / 3$ of the scour hole depth. The rock scour protection comprised an angular gravel with density of $2670 \mathrm{~kg} / \mathrm{m}^{3}$ and median grain size of $14.1 \mathrm{~mm}$.

In Tests 3 and 6 the remediation was installed in a fully-formed scour hole, and in Test 4 the remediation was installed in a partially formed scour hole. The rock remediation was installed underwater using an inclined fall pipe (Fig. 7).

Rock armour scour protection was pre-installed in Test 5. For this test the scour protection was placed after the bed preparation but before filling the flume or installing the pile. The scour protection was installed using a template (Fig. 7), with a distance of $400 \mathrm{~mm}$ from the pile wall to the crest, edge slope of $1 \mathrm{~V}: 3 \mathrm{H}$, and a protection thickness of $75 \mathrm{~mm}$.

\subsubsection{Tyre-Filled Nets}

Tyre-filled net (TFN) scour protection systems have been installed at a small number of offshore sites. They are designed to trap sediment and hence prevent further scour developing.

During Test 2 a set of generic tyre-filled nets was installed as scour remediation in a fully-formed scour hole. Rubber model truck tyres (approximate dimensions: $26 \mathrm{~mm}$ inside diameter, $42 \mathrm{~mm}$ outside diameter, $11 \mathrm{~mm}$ wide, $1 \mathrm{~mm}$ wall thickness) were placed in nylon mesh bags, with a mesh size of approximately $2-3 \mathrm{~mm}$. The TFNs were installed by lowering into place as two rings of six nets (Fig. 8). 50 tyres were placed in each net, making 600 tyres in total.

\section{EXPERIMENT RESULTS}

\subsection{Bathymetry Measurements}

During the Fast Flow Facility experiments, bed levels were measured using an underwater laser scanner at scheduled pauses in the flume operation, and also at the end of each test using a terrestrial laser scanner. Fig. 9 presents an example of the typical data acquired from the underwater laser scanner. Whilst coverage was limited, by the water clarity and by line of sight obstructions such as the pile, good data for scour evolution were obtained.

The bathymetry data were analysed to extract local embedment levels and global bed levels by statistical analysis of data in the areas of interest (Fig. 9). The global bed levels have a greater range of measurements due to transient bed-forms moving through the test section. 


\subsection{Natural Frequency Measurements}

The tower-structure model included a variable top mass, which enabled the structural response to be systematically varied. Fig. 10 presents an example of the top mass versus measured frequency. Table 4 presents a subset of the natural frequency measurements at the start of each test, with $3.616 \mathrm{~kg}$ top mass attached. These natural frequencies were calculated using time-domain fitting of decaying
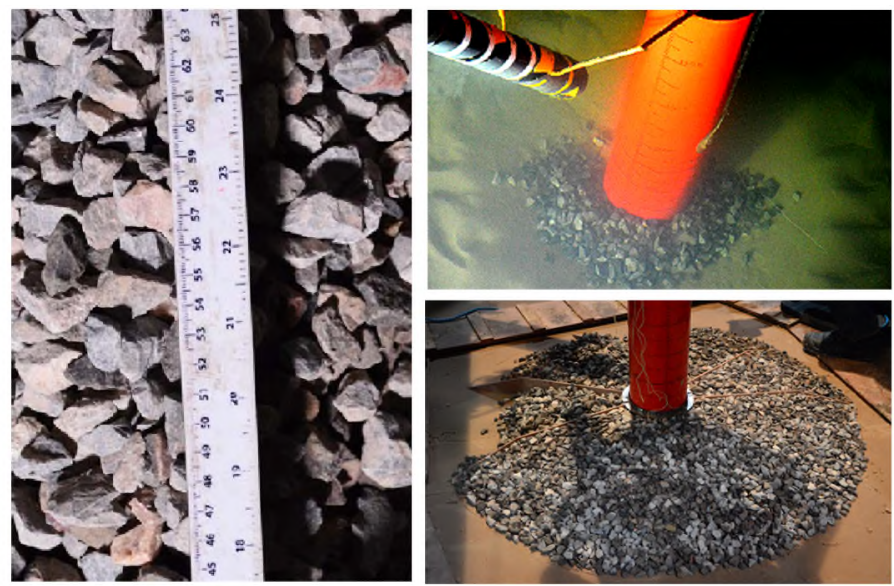

Figure 7. Rock armour scour protection at model scale. (Left: rock detail; Top right: Installation of remediation by fall pipe; Bottom right: Pre-installation of protection using templates).
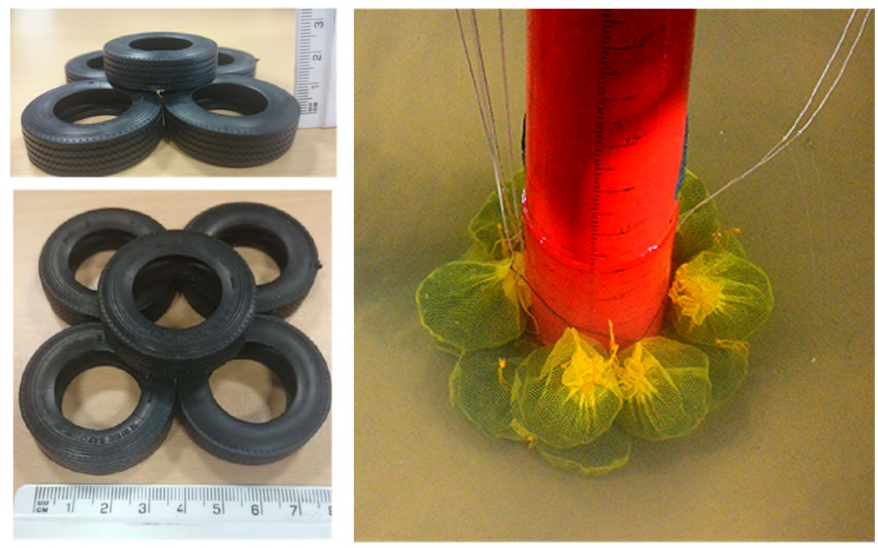

Figure 8. Tyre-filled net scour protection at model scale (Left: tyre detail; Right: Installation of tyre-filled nets).
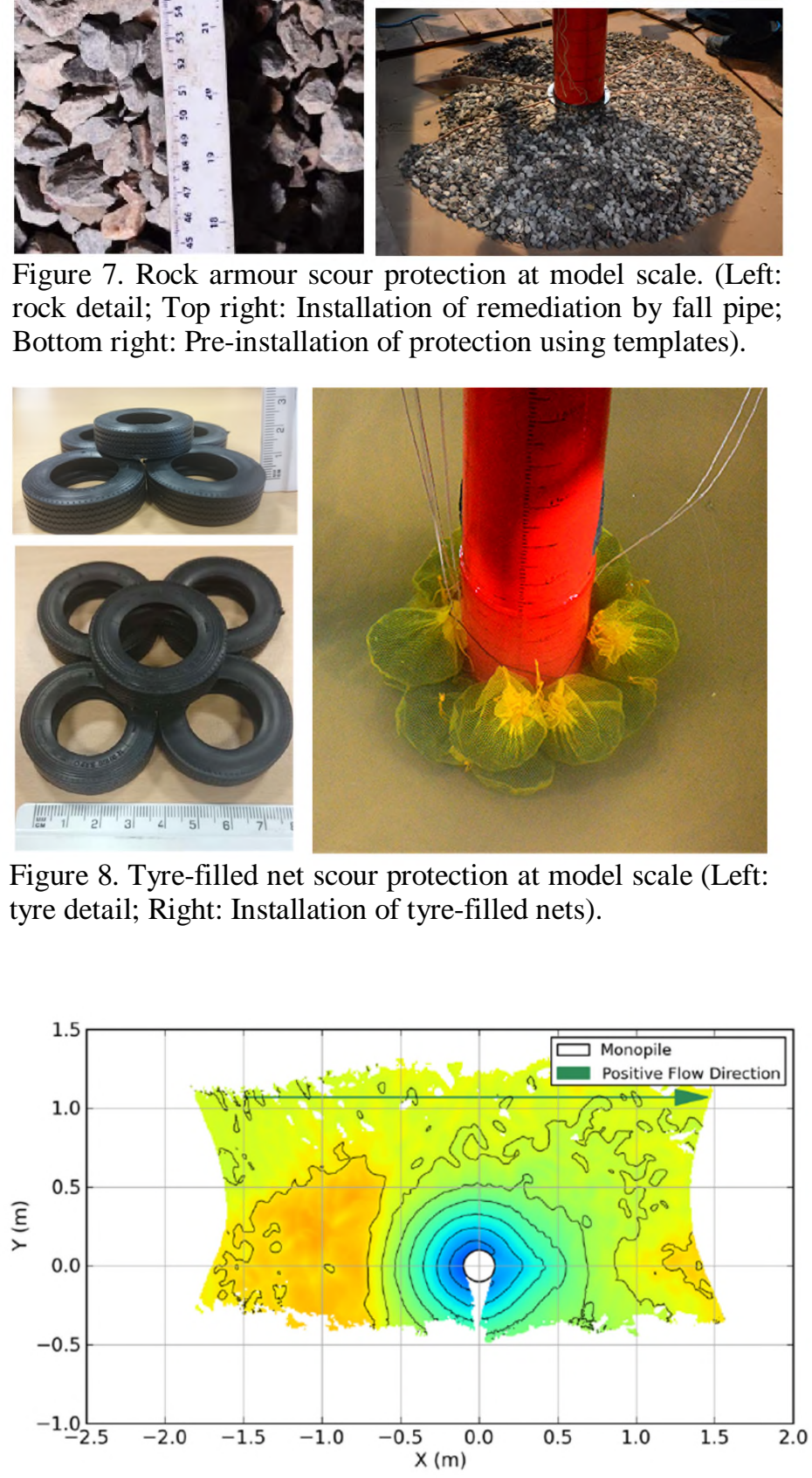

acceleration signals following an impulse load.

\subsection{Effect of Scour on Natural Frequencies}

One of the central aims of the Fast Flow Facility experiments performed at HR Wallingford was to provide natural frequency and scour measurements for validation and calibration of the proposed numerical models.

Fig. 11 presents the change in frequency for the first three modes of vibration during the local scour stage of the Fast Flow Facility experiments for the subset of top mass $=3.616 \mathrm{~kg}$. From these plots it can be observed that mode 2 is the most sensitive to scour. These data indicate that the natural frequency of mode 2 reduces approximately four times more rapidly than mode 1 , and mode 3 reduces approximately two times more rapidly than mode 1 . Differences in sensitivity between tests are most likely caused by variations in the achieved soil

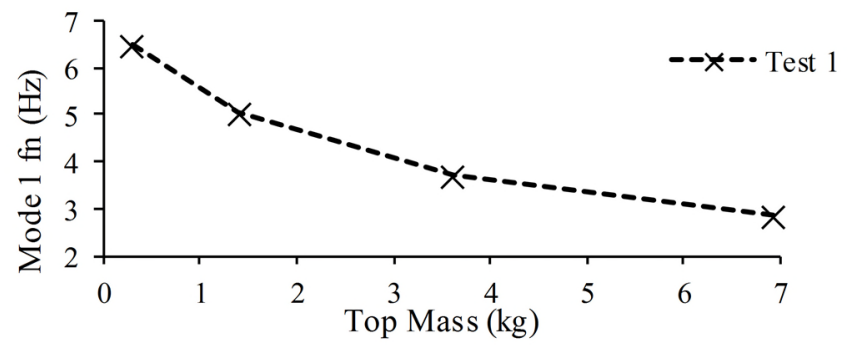

Figure 10. Example of measured natural frequency versus top mass (Mode 1, start of Test 1).

Table 4. Initial Natural Frequency Measurements from Fast Flow Facility Experiments (top mass $=3.616 \mathrm{~kg}$ ).

\begin{tabular}{llll}
\hline $\begin{array}{l}\text { Test } \\
\text { Number }\end{array}$ & $\begin{array}{l}\text { Initial Mode } 1 \\
f_{n}(\mathrm{~Hz})\end{array}$ & $\begin{array}{l}\text { Initial Mode } 2 \\
f_{n}(\mathrm{~Hz})\end{array}$ & $\begin{array}{l}\text { Initial Mode 3 } \\
f_{n}(\mathrm{~Hz})\end{array}$ \\
\hline 1 & 3.72 & 17.6 & 41.6 \\
2 & 3.72 & 17.1 & 40.9 \\
3 & 3.76 & 18.0 & 41.5 \\
4 & 3.75 & 17.3 & 41.4 \\
5 & 3.73 & 18.4 & 42.0 \\
6 & 3.80 & 19.7 & 43.9 \\
\hline
\end{tabular}

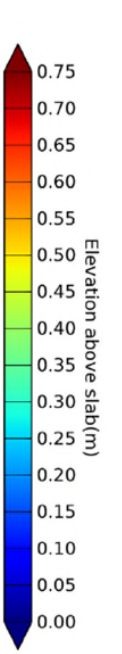

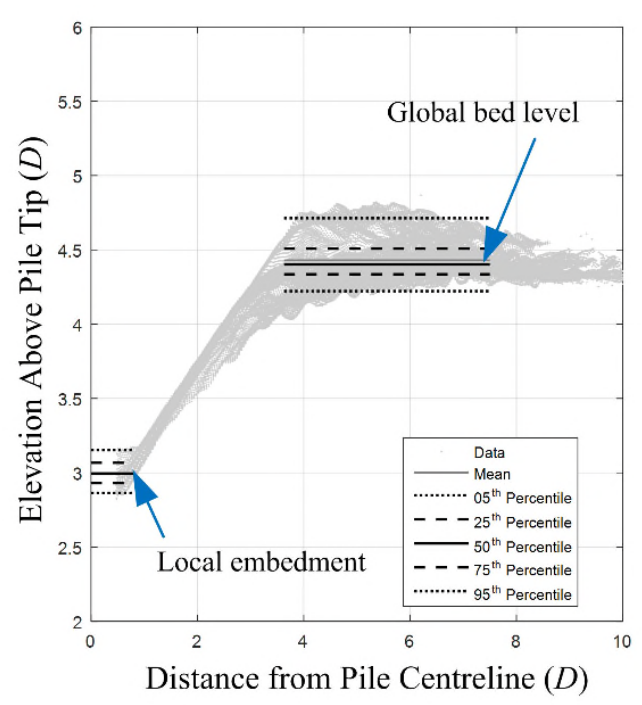

Figure 9. Underwater laser scanner bathymetry example from Test 1 , end of local scour stage

(Left: Mapped elevation of bed relative to slab datum, note that pile tip depth is $400 \mathrm{~mm}$ below slab datum; Right: Statistical analysis of local embedment and global bed level). 
conditions and experimental scatter.

Fig. 12 presents an example comparison of measured natural frequencies with Class $\mathrm{C}$ predictions from the 1D FEA at model scale. [Class $\mathrm{C}$ predictions are made with sight of the results.] In the example shown the trends of natural frequency with scour are very similar between the prediction and the experiments; the frequency of mode 1 is overpredicted by roughly $1 \%$, mode 2 is underpredicted by less than $10 \%$ and mode 3 is underpredicted by less than $5 \%$.

\subsection{Scour Protection Performance}

In all tests involving scour protection, the condition of the scour protection was identified at the end of the test through an excavation process. Key observations are noted in Table 5, which includes notes on the natural frequency measurements immediately after installing scour protection and at the end of each test following the global scouring stage.

In all tests, trapped sediment accumulated in the scour protection material, with the edges of the scour protection being partially buried by sand waves. In most tests scour protection caused the natural frequency to increase; the clearest exception is Test 4 where the scour protection material was not sufficient to maintain the local embedment, resulting in a drop in measured natural frequency.

\section{CONCLUSIONS}

The effect of scour and scour protection on monopile supported wind turbine structures is an important area of offshore design. This paper describes an ongoing research project exploring this topic at the University of Oxford including:

- 1D and 3D finite element models for predicting changes in the dynamic response of an offshore wind structure for varying scour conditions

- An experimental programme exploring the dynamic response of a 1:20 scale offshore wind
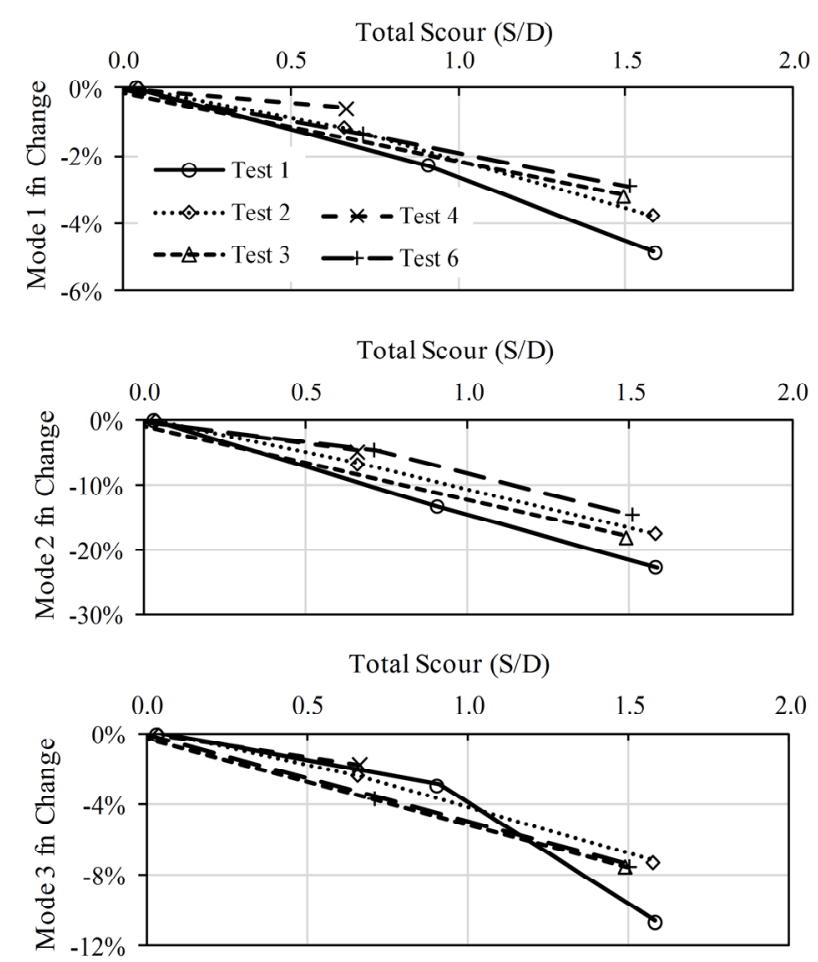

Figure 11. Measured change in natural frequencies with developing local scour (top mass $=3.616 \mathrm{~kg}$ ).
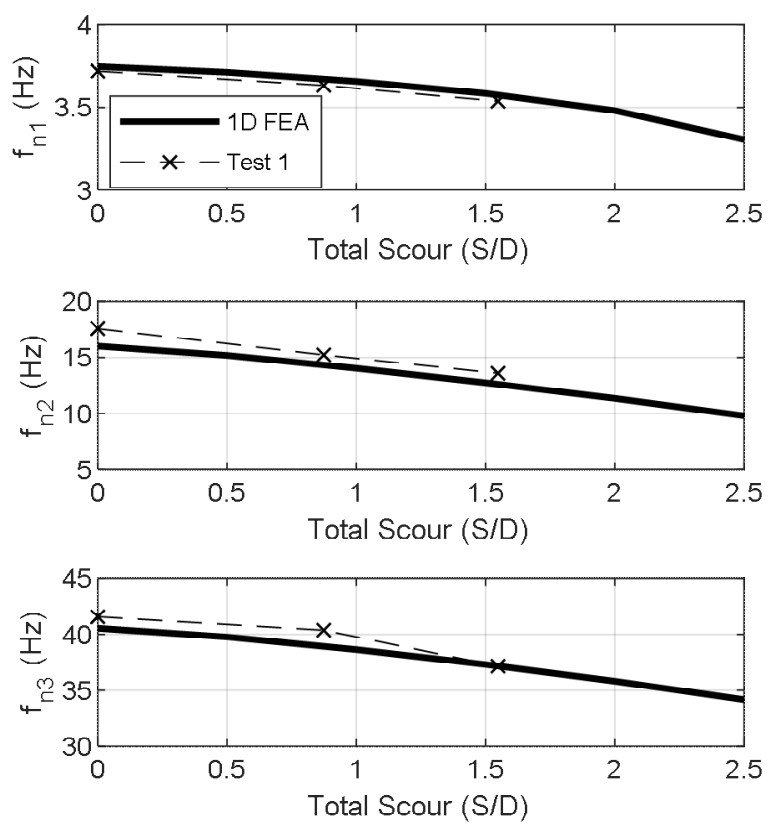

Figure 12. Comparison of 1D numerical model output with experimental data (Test 1 , top mass $=3.616 \mathrm{~kg}, \alpha_{L}=1$ ).

Table 5. Summary of Scour Protection Performance in Fast Flow Facility Experiments.

\begin{tabular}{|c|c|c|c|c|c|c|c|}
\hline \multirow[t]{3}{*}{$\begin{array}{l}\text { Test } \\
\text { Number }\end{array}$} & \multicolumn{2}{|c|}{$\begin{array}{l}\text { End of Test Bed Level } \\
\text { Above Pile Tip (Median) }\end{array}$} & \multirow[t]{3}{*}{$\begin{array}{l}\text { Observations of Scour Protection } \\
\text { Condition at End of Test }\end{array}$} & \multicolumn{4}{|c|}{$\begin{array}{l}\text { \% Change in Natural Frequency } \\
\text { (from unscoured case with top mass }=3.616 \mathrm{~kg} \text { ) }\end{array}$} \\
\hline & Global & Local Level & & After Sc & Protection & End of T & \\
\hline & Level & At Pile Wall & & Mode 1 & Mode 2 & Mode 1 & Mode 2 \\
\hline 1 & $3.99 \mathrm{D}$ & $2.24 \mathrm{D}$ & - & - & - & -7.2 & -31.2 \\
\hline 2 & $4.18 \mathrm{D}$ & $3.81 \mathrm{D}$ & Trapped sediment, nets partially buried & -3.9 & -16.5 & -3.3 & -16.0 \\
\hline 3 & $4.27 \mathrm{D}$ & $3.87 \mathrm{D}$ & Trapped sediment, rock partially buried & -2.8 & -17.3 & -2.7 & -12.0 \\
\hline 4 & $4.18 \mathrm{D}$ & $3.83 \mathrm{D}$ & $\begin{array}{l}\text { Trapped sediment, falling apron of rock } \\
\text { falling apron partially buried }\end{array}$ & -0.4 & -2.5 & -2.8 & -10.4 \\
\hline 5 & $4.11 D$ & $4.84 \mathrm{D}$ & $\begin{array}{l}\text { Trapped sediment, falling apron of rock, } \\
\text { surface rocks undisturbed }\end{array}$ & - & - & +0.3 & +1.5 \\
\hline 6 & $3.82 \mathrm{D}$ & $5.05 \mathrm{D}$ & Trapped sediment, falling apron of rock & -2.3 & -8.1 & -1.6 & -9.5 \\
\hline
\end{tabular}


structure with scour and with scour protection

The experimental programme has produced a significant data set, including bathymetry measurements and natural frequency measurements for a range of modelled rotor-nacelle masses. Key findings from the experimental programme thus far are:

- The frequency of second and third vibration modes are more sensitive to scour than the frequency of the first vibration mode

- The testing method achieved global scouring of the test bed, with significant bed-forms causing spatial variation in the global levels

- In tests with scour protection, sediment was deposited within the scour protection material

- The natural frequency of structures with scour protection increased or remained stable after further flow in cases where the scour protection level at the pile wall did not reduce significantly

The experimental data will be used for calibration and validation of the numerical models, including the following elements of the analysis:

- Soil stress and stiffness profiles for small displacement problems with local scour

- Modelling the stiffness contribution of scour protection material with global and local scour

\section{ACKNOWLEDGEMENTS}

This research project is supported through funding from E.ON Climate \& Renewables and HR Wallingford, and by grant EP/L016303/1 for Cranfield University and the University of Oxford, Centre for Doctoral Training in Renewable Energy Marine Structures - REMS (http://www.remscdt.ac.uk/) from the UK Engineering and Physical Sciences Research Council (EPSRC).

\section{REFERENCES}

API, 2011. RP 2GEO. Recommended Practice for Geotechnical Foundation Design Consideration.

Breusers, H.N.C., Nicollet, G. \& Shen, H.W., 1977. Local scour around cylindrical piers. Journal of Hydraulic Research, 15(3), pp.211-252.

Byrne, B.W., McAdam, R.A., Burd, H.J., Houlsby, G.T., Martin, C.M., Zdravkovic, L., Taborda, D.M.G., Potts, D.M., Jardine, R.J., Sideri, M., Schroeder, F.C., Gavin, K., Doherty, P., Igoe, D., Muir Wood, A., Kallehave, D. \& Skov Gretlund, J., 2015. New design methods for large diameter piles under lateral loading for offshore wind applications. In: 3rd International Symposium on Frontiers in Offshore Geotechnics (ISFOG 2015). Oslo, Norway, June (pp. 10-12).
Clayton, C.R.I., 2011. Stiffness at small strain: research and practice. Géotechnique, 61(1), pp.5-37.

Damgaard, M., Ibsen, L.B., Andersen, L.V. \& Andersen, J.K., 2013. Cross-wind modal properties of offshore wind turbines identified by full scale testing. Journal of Wind Engineering and Industrial Aerodynamics, 116, pp.94-108.

DNVGL, 2016. Standard DNVGL-ST-0126, Support structures for wind turbines, Edition April 2016.

Høgedal, M. \& Hald, T., 2005. Scour assessment and design for scour for monopile foundations for offshore wind turbines. In: Proceedings of the Copenhagen Offshore Wind. Copenhagen, Denmark.

International Organization for Standardization (ISO), 2007. ISO 19902 Petroleum and natural gas industries - Fixed steel offshore structures. Geneva: ISO.

Kallehave, D., Byrne, B.W., LeBlanc Thilsted, C. \& Mikkelsen, K.K., 2015. Optimization of monopiles for offshore wind turbines. Phil.Trans.R.Soc.A 373: 20140100. http://dx.doi.org/10.1098/rsta.2014.0100

Larsen, S.M., Roulund, A., Brooks, A.J. and Chaffey, A., 2016. Sandwaves and megaripples at Race Bank (UK) offshore windfarm. In: $8^{\text {th }}$ International Conference on Scour and Erosion (ICSE 2016). Oxford, UK.

Mayall, R.O., McAdam, R.A., Byrne, B.W., Burd, H.J., Sheil, B.B., Cassie, P., \& Whitehouse, R.J.S., 2018. Experimental modelling of the effects of scour on offshore wind turbine structures. In: $9^{\text {th }}$ International Conference Physical Modelling in Geotechnics (ICPMG 2018). London, UK, July.

Prendergast, L.J., Gavin., K. \& Doherty, P., 2015. An investigation into the effect of scour on the natural frequency of an offshore wind turbine. Ocean Engineering 101 1-11.

Prendergast, L.J., Reale, C. \& Gavin, K., 2018. Probabilistic examination of the change in eigenfrequencies of an offshore wind turbine under progressive scour incorporating soil spatial variability. Marine Structures 57 87-104

Qi, W.G., Gao, F.P., Randolph, M.F. \& Lehane, B.M., 2016. Scour effects on $\mathrm{p}-\mathrm{y}$ curves for shallowly embedded piles in sand. Géotechnique, 66(8), pp.648-660.

Sørensen, S.P.H. \& Ibsen, L.B., 2013. Assessment of foundation design for offshore monopiles unprotected against scour. Ocean Engineering 63 17-25.

Tavouktsoglou, N.S., Harris, J.M., Simons, R.R. \& Whitehouse, R.J.S., 2017. Equilibrium Scour-Depth Prediction around Cylindrical Structures. J. Waterway, Port, Coastal, Ocean Eng., 143(5): 04017017.

Tempel, J., Zaaijer, M.B. \& Subroto, H., 2004. The effects of Scour on the design of Offshore Wind Turbines.

Tseng, W., Kuo, Y., Chen, J., 2017. An Investigation into the Effect of Scour on the Loading and Deformation Responses of Monopile Foundations. In: Energies 2017, 10, 1190.

Zdravković, L., Taborda, D.M.G., Potts, D.M., Jardine, R.J., Sideri, M., Schroeder, F.C., Byrne, B.W., McAdam, R., Burd, H.J., Houlsby, G.T. \& Martin, C.M., 2015. Numerical modelling of large diameter piles under lateral loading for offshore wind applications. In: 3rd International Symposium on Frontiers in Offshore Geotechnics (ISFOG 2015). Oslo, Norway. 